AGRO EKONOMI, Vol 29, Issue 2, December 2018, Page.218-230

DOI : http://doi.org/10.22146/ae.35888

ISSN 0215-8787 (print), ISSN 2541-1616 (online)

Available at https://jurnal.ugm.ac.id/jae/

\title{
LEVEL OF CUSTOMER SATISFACTION TOWARDS MARKETING MIX IN INDONESIAN TRADITIONAL MARKET
}

\section{Tingkat Kepuasan Konsumen Terhadap Penerapan Bauran Pemasaran di Pasar Tradisional di Indonesia}

\author{
Ratih Dwi Kartikasari ${ }^{1}$, Irham ${ }^{2}$, Jangkung Handoyo Mulyo ${ }^{3}$ \\ ${ }^{1}$ Agribusiness, Universitas Tunas Pembangunan \\ Faculty of Agriculture, ${ }^{2,3}$ Universitas Gadjah Mada \\ ${ }^{1} \mathrm{~J} 1$. Balekambang Lor No 1 Manahan, Surakarta \\ ${ }^{2,3} \mathrm{Jl}$. Flora No. 1 Bulaksumur, Yogyakarta 55281 \\ ratihkartika14@gmail.com
}

Submitted: 28 May 2018; Revised: 23 September 2018; Accepted: 26 September 2018

\begin{abstract}
The competition of various shopping centers in attracting consumers is getting more intense due to the increased consumer purchasing power. Many studies show that consumers are more interested to shop in a modern market, which has many attractive facilities, but only a few studies have examined the satisfaction of consumers shopping in traditional markets. The purpose of this study was to examine the level of customer satisfaction in traditional markets and to find out the priority strategies for improving traditional market performance. The data was analyzed using the Customer Satisfaction Index (CSI) and Importance Performance Analysis (IPA). Non-probability sampling was employed with an accidental sampling technique to as many as 180 customers in 8 traditional markets in Indonesia. Based on the research analysis, the CSI value obtained was $74.25 \%$, showing that the customers were satisfied with the performance of traditional market merchants. The most considered marketing mix attribute to consumers in shopping was the friendliness of merchants when serving their consumers. This means that consumers did not only pay attention to the type of products purchased but also consider the services they received in the transaction. The priority strategy that needs to be done is to maintain the performance of attributes in Concentrate Here quadrant which consist of product availability, market hygiene, product price in line with expectations, lower product price, additional free product for certain quantity purchase, and discounted price from merchants.
\end{abstract}

Keywords: CSI, IPA, marketing mix, traditional market.

Kartikasari, R.D., Irham.,\& Mulyo, J.H (2018) Level of Customer Satisfaction Towards Marketing Mix in Indonesian Traditional Market. Agro Ekonomi, 29(2) : 218-230

\section{INTISARI}

Persaingan berbagai pusat perbelanjaan dalam menarik konsumen semakin tinggi terlebih dengan daya beli masyarakat yang semakin meningkat. Banyak penelitian menunjukkan konsumen semakin senang berbelanja di pasar modern yang memiliki fasilitas menarik. 
Namun hanya sedikit study yang meneliti kepuasan konsumen terhadap kinerja pasar tradisional. Studi ini menguji bagaimana tingkat kepusan konsumen berbelanja di pasar tradisional serta mengetahui strategi prioritas untuk peningkatan kinerja pasar tradisional. Metode yang digunakan adalah metode Customer Satisfaction Index (CSI) dan Importance Performane Analysis (IPA). Pengambilan sampel dilakukan secara non probability sampling dengan teknik accidental sampling sebanyak 180 konsumen pada 8 pasar tradisional di Indonesia. Berdasarkan hasil penelitian nilai CSI yang diperoleh adalah 74,25\% yang berarti konsumen puas berbelanja di pasar tradisional. Atribut bauran pemasaran yang paling dipertimbangkan konsumen dalam berbelanja adalah keramahan pedagang dalam melayani konsumen. Hal ini berarti bahwa konsumen tidak hanya memperhatikan jenis produk yang dibeli akan dibeli tetapi juga mempertimbangkan pelayanan yang diterima. Strategi prioritas yang perlu dilakukan adalah mempertahankan kinerja atribut pada kuadran Concentrate Here yang terdiri dari faktor ketersediaan produk, kebersihan pasar, harga produk sesuai dengan harapan, harga produk lebih murah, tambahan produk gratis untuk pembelian jumlah tertentu, serta adanya potongan harga dari pedagang.

Kata kunci: bauran pemasaran, CSI, IPA, pasar tradisional.

\section{INTRODUCTION}

Traditional market is the economic base of the people that has the potential and is able to move the wheels of the economy. According to the Indonesian Presidential Regulation No.112 of 2007, traditional markets are markets that are built and managed by the government, local government, private sector, BUMN, and BUMD, including cooperation with the private sector with businesses in the form of shops, kiosks, and tents owned or managed by small, medium, nongovernmental, or cooperative traders with small scale business or small capital and by the process of buying and selling goods through bargaining. Martin (2017) stated that traditional markets have the potential economically and socially in the society. Some of the reasons why customers are reluctant to shop in traditional markets are because they are hot, dirty, muddy, crowded, and smelly, also because they have distant locations, uncertain prices, slight product variations, improper arrangements, and low security levels. Rianse et al., (2013) mentioned that prices in traditional markets are sometimes more expensive when compared to the price of products offered by village cooperatives.

Traditional market participants, especially merchants, should pay attention to customer needs, in terms of both quantity and quality. Retailers have always worked to establish close relationships with customers through the retail marketing mix, said Blut et al., (2018). Meanwhile, according to Malik et al., (2012), customer satisfaction is considered as the most important factor to gain a competitive advantage in the business world. Customer satisfaction influences both success and sustainability of a business. 
(Dwi \& Rachmina (2011) stated that some factors affecting customer satisfaction are the availability of products, ease of reaching outlets, cleanliness of outlets, atmosphere of outlets, and ease of payment. Devani \& Rizko (2016) showed a CSI index value of about $70.44 \%$ indicating that most customers have been satisfied with the services.

Amofah \& Gyamfi (2016), Meesala \& Paul (2018), and Verma \& Singh (2017) demonstrated the importance of marketing mix and customer satisfaction to shape new policies and analyze the growth of service industry. Assessing market conditions can be done with regard to customers as the target market because customers are the main target of the products offered. Many studies showed that consumers are increasingly interested in shopping in modern markets that have excellent facilities. However, only a few studies examined consumer satisfaction from shopping in traditional markets. Understanding the effectiveness of different instruments on retail helps to explain why customers shop where they do (Blut et al., 2018). This study examined the level of Indonesian customer satisfaction when selecting traditional markets as their shopping location and the strategies to be the main reasons for consumers to shop in traditional markets.

\section{METHODS}

The research locations were determined using the purposive method resulting in Andolou Utama Market (DU) of South Konawe District, Aceh Besar Market of Saree District, Sukamandi Market and Kelapa Kampit Market of East Belitung District, Caplek Market and Wringin Market of Cilacap District, Sedo Demak Market of Demak District, and Bululawang Market of Malang District. The chosen markets were the target markets of optimization program for rural market development in 2017 by the Ministry of Villages, Development of Disadvantaged Regions, and Transmigration of the Republic of Indonesia. Non-probability sampling method with the accidental sampling technique has been used to select 180 respondents as the samples in this research. Interviews were conducted with a questionnaire tool consisting of several questions with answer choices in the form of a Likert scale. This is in accordance with Suryani \& Hendryadi (2015) who mentioned that the size of multivariate study samples is several times larger (10 times) than the variables analyzed. In this research, the analysis was done with the following stages (Maryono, 2016):

\section{Customer Satisfaction Index (CSI)}

CSI was used to measure the level of customer satisfaction through the calculation of consumer ratings on performance of indicators attached to the item/service. The step to measure the level of customer satisfaction was by calculating the customer 
satisfaction index. The value of CSI can be written systematically as follows:

$$
\begin{aligned}
& \text { MIS- } i=\frac{\sum_{i=1}^{\mathrm{H}} \mathrm{Y}_{\mathrm{i}}}{\mathrm{n}} \\
& \mathrm{MSS}-\mathrm{i}=\frac{\sum_{\mathrm{i}=1}^{\mathrm{H}} \mathrm{Xi}}{\mathrm{n}} \\
& \mathrm{WF}-\mathrm{i}=\frac{\mathrm{MIS}-\mathrm{i}}{\sum \mathrm{MIS}} \\
& \mathrm{WS}-\mathrm{i}=\mathrm{MSS}-\mathrm{i} \times \mathrm{WF}-\mathrm{i} \\
& \mathrm{WT}=\mathrm{WS}_{1}+\mathrm{WS}_{2}+\ldots \ldots .+\mathrm{WS}_{\mathrm{n}} \\
& \mathrm{CSI}=\frac{\mathrm{WT}}{\mathrm{HS}} \times 100 \%
\end{aligned}
$$

Notes :

MIS-i $=$ Mean Importance Score factor i

MSS-i $=$ Mean Satisfaction Score factor i

$\mathrm{n} \quad=$ number of respondent

$\mathrm{Xi} \quad=$ value of merchants performance level according to consumers

Yi $=$ value of customer important level

WF-i $=$ Weight Factor $\mathrm{i}$

WS-i $=$ Weight Score factor $\mathrm{i}$

WT $=$ Weight Total

CSI = Customer Satisfaction Index

HS = Highest Score

Criteria for the level of CSI in the marketing mix for traditional markets were $0.00 \leq \mathrm{n} \leq 20.99$ in very low category, $21.00 \leq \mathrm{n} \leq 40.00$ in low category, $41.00 \leq$ $\mathrm{n} \leq 60.99$ in medium category, $61.00 \leq \mathrm{n}$ $\leq 80.99$ in high category, and $81.00 \leq \mathrm{n} \leq$ 100 in very high category (Maryono, 2016).

2. Importance Performance Analysis (IPA)

IPA was first introduced by Martilla \& James (1977). This model aims to measure the relationship between consumer perceptions and priority of product/service quality improvement, which is also known as quadrant analysis. Calculation was produced regarding the level of suitability between importance and performance level to be applied for developing the management strategies to improve customer satisfaction. The steps of IPA analysis were as follows:

$$
\begin{aligned}
& \overline{\mathrm{X}}_{\mathrm{i}}=\frac{\sum \mathrm{X} \mathrm{i}}{\mathrm{n}} \overline{\mathrm{Y}}_{\mathrm{i}} \mathrm{i}=\frac{\sum \mathrm{Y} \mathrm{i}}{\mathrm{n}} \\
& \overline{\overline{\mathrm{X}}}_{\mathrm{i}}=\frac{\sum \overline{\mathrm{X}} \mathrm{i}}{\mathrm{K}} \overline{\overline{\mathrm{Y}}}_{1}=\frac{\sum \overline{\mathrm{Y}} \mathrm{i}}{\mathrm{K}}
\end{aligned}
$$

Notes :

$\overline{\mathrm{X}} \mathbf{j}=$ average level of merchants performance according to consumers $\overline{\mathrm{Y}} \mathrm{j}=$ average customer interest level

$\overline{\bar{X}} \mathbf{j}=$ average of the average value of merchants performance level according to consumers

$\overline{\bar{Y}} 1=$ average of the average value of customer importance

$\mathrm{K}=$ the number of indicator used

\section{RESULTS AND DISCUSSION}

\section{Level of Customer Satisfaction}

Satisfaction is one of the indicators showing the willingness of customers to repurchase. Maintaining and improving customer satisfaction are important for merchants to survive in business competition. The research found that the CSI value is 3.7123 on a maximum scale of 5, or in the form of percentage, CSI in traditional markets is $74.25 \%$. It means that 
customer satisfaction in traditional markets is classified as high and categorized as satisfied. Satisfied customers make repeat purchases and they tell others about their good experiences with the product. The key of business success is to match customer expectations with company performance (Mukesh, 2014). Based on Table 1, the highest score weight is the merchants' friendliness to buyers with a value of 0.1975 while the lowest score weight is the attribute of promotional information of merchants through media. This is due to the lack of promotion by merchants and traditional market managers to attract customers.

Customers are satisfied with the services in traditional markets that still prioritize kinship system to provide convenience to customers in the transaction. This finding is in line with the results of previous studies (Srivastava \& Kaul, 2014; Söderlund \& Sagfossen, 2017; and Söderlund, 2018). Friendly, honest, and vigorous merchant services have more value for customers as a consideration of shopping in traditional markets. Traditional merchants' hospitality is demonstrated by the willingness to greet customers making customers feel they have different social values from modern markets. Honesty is the basis of the trust that customers give to merchants, so it is necessary to maintain. Mukesh (2014) found that customers are very comfortable and convenient to purchase the products from traditional retail rather than from supermarkets. Customers go to traditional retail stores because of a wide variety of products, price deduction on total purchase, free home delivery, good packing, and excellent services from salespersons. Traditional retail stores are also open for long hours and sometimes on all days. Traditional retail offers a friendly personal service because customers are known to the retailer, which therefore allows small credit, self-service without making the customers wait for long. Although there is interaction between merchants and customers, this does not interfere with merchants to serve customers swiftly.

\section{Priority Strategies}

Based on the CSI value, it can be concluded that some attributes of marketing mix according to customer perception have not been done optimally. Therefore, it is necessary to determine priority strategies to improve traditional market performance using IPA method. Eboli \& Mazzula (2009) explained that stages in IPA analysis consider the level of interest and customer satisfaction. Cartesius diagram is used to determine the position of each attribute of customer satisfaction, whether each is located in the position to be repaired or maintained. Using Cartesius diagram, the attribute location in Concentrate Here, Keep up the Good Work, Low Priority, or Possible Overkill quadrants can be observed 
Table 1. All Attributes CSI Value Calculation

\begin{tabular}{|c|c|c|c|c|}
\hline Attribute (1) & $\begin{array}{c}\text { Mean } \\
\text { Importance } \\
\text { Score } \\
\text { MIS (2) }\end{array}$ & $\begin{array}{c}\text { Weight } \\
\text { Factor } \\
\text { WF (3) } \\
(2) / \text { total }\end{array}$ & $\begin{array}{c}\text { Mean } \\
\text { Satisfaction } \\
\text { Score } \\
\text { MSS (4) }\end{array}$ & $\begin{array}{l}\text { Weight } \\
\text { Score } \\
\text { WS (5) }= \\
(3) \times(4)\end{array}$ \\
\hline \multicolumn{5}{|l|}{ Product } \\
\hline Product information & 3.84 & 0.042 & 3.81 & 0.1599 \\
\hline Product diversity & 4.17 & 0.045 & 3.78 & 0.1708 \\
\hline Product packaging & 3.73 & 0.041 & 3.48 & 0.1409 \\
\hline \multicolumn{5}{|l|}{ Price } \\
\hline Lower product price & 4.06 & 0.044 & 3.31 & 0.1457 \\
\hline Price developments & 3.77 & 0.041 & 3.69 & 0.1510 \\
\hline Bargain product prices & 4.03 & 0.044 & 3.77 & 0.1651 \\
\hline Product price in line with expectation & 4.21 & 0.046 & 3.51 & 0.1600 \\
\hline \multicolumn{5}{|l|}{ Place } \\
\hline Identity stall & 3.06 & 0.033 & 3.47 & 0.1152 \\
\hline Product availability & 4.23 & 0.046 & 3.38 & 0.1554 \\
\hline \multicolumn{5}{|l|}{ Promotion } \\
\hline Discounted price from merchants & 3.88 & 0.042 & 3.68 & 0.1550 \\
\hline $\begin{array}{l}\text { Additional free product for certain quantity } \\
\text { purchase }\end{array}$ & 4.01 & 0.044 & 3.49 & 0.1521 \\
\hline Word of mouth promotion & 2.68 & 0.029 & 3.27 & 0.0949 \\
\hline Media promotion & 2.53 & 0.027 & 3.19 & 0.0876 \\
\hline \multicolumn{5}{|l|}{ People } \\
\hline Merchants managing his/her own business & 3.63 & 0.039 & 3.94 & 0.1555 \\
\hline Merchants alertness & 4.22 & 0.046 & 4.07 & 0.1866 \\
\hline Merchants friendliness & 4.33 & 0.047 & 4.20 & 0.1975 \\
\hline Merchants honesty & 4.34 & 0.047 & 4.03 & 0.1899 \\
\hline \multicolumn{5}{|l|}{ Process } \\
\hline Packaging process & 3.71 & 0.040 & 3.63 & 0.1461 \\
\hline Flexible payments & 3.82 & 0.041 & 3.84 & 0.1592 \\
\hline Delivery order facility & 3.33 & 0.036 & 3.44 & 0.1244 \\
\hline \multicolumn{5}{|l|}{ Physical Evidence } \\
\hline Strategic market location & 4.13 & 0.045 & 4.07 & 0.1827 \\
\hline Market hygiene & 4.24 & 0.046 & 3.64 & 0.1676 \\
\hline Neat product arrangement & 4.03 & 0.044 & 3.87 & 0.1693 \\
\hline Customer convenience in shopping & 4.17 & 0.045 & 3.98 & 0.1799 \\
\hline Total & 92.15 & & & 3.7123 \\
\hline \multicolumn{4}{|c|}{ CSI Value } & $74.25 \%$ \\
\hline
\end{tabular}

Source : Primary Data (2017)

and the results can be further implemented. The position of each attribute on the four quadrants is used as an alternative strategy tool to improve performance in traditional markets that brings impact on customer satisfaction.

\section{a. Concentrate Here Quadrant}

\section{Market hygiene}

The cleanliness of the market environment is a common thing that should not be ruled out. Trash from the rest of the product sales that is not removed will 
cause unpleasantness, such as stink and low aesthetic value generated. Customers will feel more comfortable when the place is clean which is related to health and comfort. This finding is relevant with the findings of a previous study (Martínez-Ruiz et al., 2010).

\section{Product availability}

Customers are satisfied when they find the product they are looking for in the shopping location. In contrast, customers will feel disappointed if the product sought is not found in the shopping location, which will affect the willingness of customers to buy back in the same location.

\section{Product price in line with expectation}

The price is one of the aspects that become main consideration for customers in determining the shopping location. The product pricing will be adjusted to the quality of the goods as well as various other factors to be charged such as tax of the place for selling. Price-conscious and low-income shoppers put less emphasis on convenience and service in stores. Conversely, customers living in high GDP countries can afford not only satisfying higher needs but also different preferences for products and services (Hsieh et al., 2004). Based on the research results, the price of the product is still highly considered compared to the service, facilities, and product quality received by customers.

\section{Lower product price}

Traditional market merchants rarely set a high price to be negotiable. Expensive prices can be caused by several factors such as the location of a market that is difficult to reach by public transport. The price offered is not quite different with a nearby retail market. Customers expect to obtain low prices in traditional markets because the merchants' price is a key determinant of customer satisfaction (Blut et al., 2018).

Additional free product for certain quantity purchase

Customer interest to shop is not only due to discount factors provided by the merchants, but also because of the provision of bonuses to customers such as providing additional free products. The research result showed that merchants in traditional markets have not given many bonuses to customers as an effort to attract them.

\section{Discounted price from merchants}

Discounts become very effective especially when customers buy in large quantities. For customers in traditional markets, discounting is a very important aspect, but merchants in traditional markets have not given satisfactory performance because customers still have to pay full to the merchants for their products. 


\section{b. Keep Up the Good Work Quadrant}

\section{Merchants honesty}

The interaction between customers and employees has been found to affect a customer's in-store shopping experience (Terblanche, 2018). The honesty of merchants is an important aspect for customers because it affects customers' confidence in the merchants. From the research result, it is known that merchants have to be honest to provide satisfaction for customers. The scales are fit and appropriate in size and that promotional merchants do not exaggerate products intended to deceive.

\section{Merchants' friendliness}

An important point that distinguishes between modern and traditional retail markets is the business actor. Traditional market has a very thick social value. Most traditional market merchants are friendly to serve their customers. Merchants often interact with customers such as having a conversation without interrupting the transaction process.

\section{Merchants' alertness}

Merchants in traditional markets generally serve customers with alacrity according to their ability. This is done because the merchant appreciates valuable customer time, especially shopping activities in traditional markets that will take longer due to the visit to several locations.

\section{Customer convenience in shopping}

Freedom of movement is an important aspect for customers and affects the level of customer convenience in shopping. Limited space for shopping can make customers switch to other merchants. Merchants in traditional markets have tried to arrange the place of sale for customers to be free for passing by. In addition, customers can also be face to face with the merchant, and this will provide flexibility of communication enabling information submitted by merchants to be channeled optimally.

\section{Product diversity}

The good ability of traditional market merchants is also seen from the variety of their products. It is important because costumers will find it easier to seek a variety of products in the same location. Traditional markets provide raw goods such as vegetables, fruits, meat, and fish as well as finished goods such as cakes, ready-to-eat meals, clothing, and household items.

\section{Strategic market location}

From the results of the study, it is known that location becomes an important aspect for customers. A previous study found that physical environment has a significant correlation with customer satisfaction (Mahfooz, 2014). Short mileage is the right choice for people to 
shop in traditional markets, and supporting facilities and transportation infrastructure make it easier for customers to visit the market.

\section{Neat product arrangement}

Neat and attractive product structuring will certainly provide a positive impression for customers. Merchants can do this by grouping products into types, colors, or prices. Thus, customers will find it easier to choose the goods they want. A neat and easy-to-reach product setup becomes an important point for customers.

\section{Bargain product prices}

Traditional markets are a shopping place popular for their bargaining system. The seller is free to set prices for the products and the customer is entitled to bid at a lower price until an agreement is reached between the two. It cannot be found in modern markets where the product is at a fixed price. This has an impact on the psychology of customers who manage to bid because it is perceived that a lower price is obtained even though the price has been considered by the merchants to keep a profit.

\section{c. Low Priority Quadrant Product packaging}

In general, customers have brought containers to carry groceries so it has been estimated that they are the right containers. Traditional market merchants provide simple product packaging services such as plastic bags and cardboard boxes to place products according to the quantity of groceries and product types. Most of the merchants have low awareness of environmental effect of using plastic bags as a package.

\section{Good packaging process}

The packaging process is not an important consideration for customers to shop. Traditional market merchants pay less attention to the skills to package products, so it is common to find several types of products that should be separated are instead combined with the reason to save containers.

\section{Delivery order facility}

Customers in traditional markets assess the delivery aspect as not important and that the performance of merchants has not been satisfactory. Customers prefer buying directly and bringing their own products after shopping to using delivery service. This is because customers will buy in the amount corresponding to the transportation used.

\section{Identity stall}

Customers in traditional markets rarely pay attention to the existence of plank sign on kiosks to determine which store to go. This is because customers memorize the location and name of the 
merchant's subscription to shop. Similarly, most merchants in traditional markets do not pay attention to the importance of plank sign installation or kiosk identity because the location of merchants who do not move even with the scale of business is very small.

\section{Word of mouth promotion}

Some customers' reason for making a purchase is due to personal experience or the recommendation of others. Based on the research results, it is known that the recommendation of others for traditional market customers is not important, especially with merchants in traditional markets that have less emphasis on customers conveying satisfaction to other customers. This finding is relevant with the findings of a previous study from Blut et al. (2018) in that promotions are intended to attract shoppers and encourage additional spending but do not effect customer satisfaction.

\section{Media Promotion}

Traditional markets do not have a media campaign to attract customers. In addition to capital limitations, the limited knowledge of merchants, mostly villagers, is also a constraint to promotion using media. Customers generally shop in traditional markets only because of the habit. Expert customers use more information sources and have domain expertise, while novice shoppers rely on fewer information sources, such as advertising (Evanschitzky et al., 2015). Lacking helpful personal experience with a retailer, advertising is more relevant for novice customers.

\section{d. Possible Overkill Quadrant \\ Product information}

Customers are accustomed to shopping for the same product and almost recurring in a short time in traditional markets. Customers find it too long to ask or listen to product information from merchants. This means that not all customers are happy with merchants who are too active in providing information related to the products so that it interferes with customer convenience in shopping.

\section{Flexible payments}

From the results of the study, it is noted that most customers do not make debt to merchants due to several factors such as the distance of the house that is not close to the traditional markets. Customers have prepared enough money in accordance with the groceries. They consider a flexible payment aspect (ability to lend) as an unimportant aspect even if the merchant provides the convenience to do so.

\section{Price developments}

Price-sensitive customers will be concerned with information regarding price 
changes. It aims not to be easily fooled when shopping in traditional markets. The results show that customers are less concerned about whether merchants understand price developments or not. However, in traditional markets, it is easy to find merchants who charge different prices and are far adrift for selling the same products. This makes customer satisfaction reduced because they have to find merchants who sell at high prices and are not in accordance with the conditions that occur.

\section{Merchants managing his/her own business}

Based on the results of the study, traditional market customers assess the merchant who manages his/her own business as an unimportant aspect. Customers do not feel the differences in service between merchant shop owners or employees. Similarly, there is no price difference that may be given by merchant shop owners or employees.

\section{CONCLUSION AND SUGGESTION}

Based on the Customer Satisfaction Index analysis, customers in traditional markets are included in the satisfied category. Meanwhile, based on the Importance Performance Analysis, the priority strategy that must be done by merchants and market managers is to improve performance of marketing mix attributes in the quadrant of
Concentrate Here. Customer satisfaction can be made better by improving the performance of merchants and market managers as well as through government intervention to provide coaching for traditional market merchants. On the other hand, traditional market management must be improved especially on the availability of products by doing regular product scheduling and improving cleanliness of the location that can be done with the addition of waste bins that are easy to reach. It is because these two factors are the most important attributes to influence consumer satisfaction, but they have not been done by traditional market management.

\section{REFERENCES}

Amofah, O., \& Gyamfi, I. (2016). The Influence of Service Marketing Mix on Customer Choice of Repeat Purchase of Restaurant in Kumasi , Ghana. European Journal of Business and Management, 8(11), 102-112.

Blut, M., Teller, C., \& Floh, A. (2018). Testing Retail Marketing-Mix Effects on Patronage: A Meta-Analysis. Journal of Retailing, 94(2), 113-135.

Devani, V., \& Rizko, R. A. (2016). Metode Customer Satisfaction Index (Csi) Dan Potential Gain in Customer Value ( PGVC ). Jurnal Rekayasa Dan Manajemen Sistem Informasi, 2(2), 24-29. 
Dwi, P. R. dan R. (2011). Forum Agribisnis. Forum Agribisnis, 1(1), 58.

Eboli, L., \& Mazzula, G. (2009). A new customer satisfaction index for evaluating transit service quality. Journal of Public Transportation, 12(3), 21-37.

Heiner Evanschitzky, Iyer, G. R., Pillai, K. G., Kenning, P., \& Schütte, R. (2015). Consumer Trial, Continuous Use, And Economic Benefits Of A Retail Service Innovation: The Case Of The Personal Shopping Assistant. Journal of Business Ethics, 44, 1-47.

Hsieh, M. H., Pan, S. L., \& Setiono, R. (2004). Product-, Corporate-, And Country-Image Dimensions And Purchase Behavior: A multicountry analysis. Journal of the Academy of Marketing Science, 32(3), 251-270.

Mahfooz, Y. (2014). Relationship between Service Quality and Customer Satisfaction in Hypermarkets of Saudi Arabia. International Journal of Marketing Studies, 6(4), 10-22.

Malik, S. A., Mushtaq, A., Naseem, K., \& Malik, S. A. (2012). Examining the Relationship Among Service Quality, Customer Satisfaction and Behavioral Responses - Comparison Between Public and Private Sector Banks of Pakistan. International
Journal for Quality Research, 6(4), 365-380.

Martilla, J. A., \& James, J. C. (2013). Importance-Per Analysis, 41(1), 77-79.

Martin, I. (2017). Penerapan Kebijakan Zonasi Dalam Penataan Pasar Tradisional dan Pasar Modern Kota Bandung (Suatu Tinjauan Yuridis dari Perspektif Otonomi Daerah ). Wawasan Yuridika, 1(2), 107-138.

Martínez-Ruiz, M. P., Jiménez-Zarco, A. I., \& Izquierdo-Yusta, A. (2010). Customer Satisfaction's Key Factors In Spanish Grocery Stores: Evidence From Hypermarkets And Supermarkets. Journal of Retailing and Consumer Services, 17(4), 278-285.

Maryono, Hefni Effendi, M. K. (2016). Analisis Kepuasan Wisatawan Untuk Manajemen Pantai Di Wisata Pantai Tanjung Bira. Jurnal Pariwisata. 3(2), 94-104.

Meesala, A., \& Paul, J. (2018). Service quality, consumer satisfaction and loyalty in hospitals: Thinking for the future. Journal of Retailing and Consumer Services, 40(October 2015), 261-269.

Mukesh, H. V. (2014). C Customer Perception Towards Traditional and 
Modern Retailing. International

Journal of Business and Management Invention, 3(12), 62-65.

Rianse, I. S., Hartono, S., \& Suryantini, A. (2013). Hubungan Kinerja dan Manfaat Koperasi Pertanian di Kabupaten Kolaka. Agro Ekonomi, 24(1), 71-85.

Söderlund, M. (2018). The Proactive Employee on the Floor of the Store and the Impact on Customer Satisfaction. Journal of Retailing and Consumer Services, 43, 46-53.

Söderlund, M., \& Sagfossen, S. (2017). The Consumer Experience: The Impact of Supplier Effort and Consumer Effort on Customer Satisfaction. Journal of Retailing and Consumer Services, 39, 219-229.

Srivastava, M., \& Kaul, D. (2014). Social Interaction, Convenience and Customer Satisfaction: The Mediating Effect of Customer Experience. Journal of Retailing and Consumer Services, 21(6), 1028 1037.

Suryani and Hendryadi. (2015). Metode Riset Kuantitatif: Teori dan Aplikasi pada Penelitian Bidang Manajemen dan Ekonomi Islam. Jakarta: Prenadamedia Group.

Terblanche, N. S. (2018). Revisiting the Supermarket in-Store Customer Shopping Experience. Journal of Retailing and Consumer Services, 40, 48-59.

Verma, Y., \& Singh, D. M. R. P. (2017). Marketing Mix, Customer Satisfaction and Loyalty: an Empirical Study of Telecom Sector in Bhutan. Indian Journal of Commerce \& Management Studies, VIII(2), 121-129. 